\begin{tabular}{l}
\hline \hline THE INDIAN SOCIETY FOR HYDRAULICS \\
JOURNAL OF HYDRAULIC ENGINEERING
\end{tabular}

\title{
IRRIGATION WATER ALLOCATION IN CANAL COMMAND AREAS
}

by

\author{
P. P. Mujumdar', F.ISH S. Vedula ${ }^{1}$, M.ISH $\quad$ Suhhankar Karmakar' \\ $\begin{array}{ll}\text { P. Manavalan } & \\ & \text { P. P. Nageshwara Rao }\end{array}$
}

\begin{abstract}
This paper presents a mathematical model developed for crop water allocations in a canal corninand area. The model uses processed data on crop areas obtained from satellite imageries in updating allocation decisions in real time. Water allocations to crops are based on detailed soil moisture balance. competition among crops for available water, crop response to water allocation. rainfall in the command area and amount of available water through canal discharge in an intraseason time period. The niodel application is demonstrated with the case study of the command area of Distributary No. 36 of the Tunga Bhadra project. Processed data on crop areas lor the case study has been obtained from earlier studies carried out by Regional Remote Sensing Service Center (RRSSC), Bangalore.
\end{abstract}

KEY WORDS : Irrigation, Crop water allocation, Remote sensing, Command area.

\section{INTRODUCTION}

Irrigation water management has significant economic implications in India. In an exhaustive and lucid review of irrigation water management in India, Sarma (2002)has discussed several critical issues related with poor agricultural productivity in the country. From the review, it is clear that non-structural measures for irrigation water management need to he strengthened to ensure greater productivity. With this in view. the present paper is concerned with developing a methodology for allocation of water among crops in canal command areas under deficit water supply.

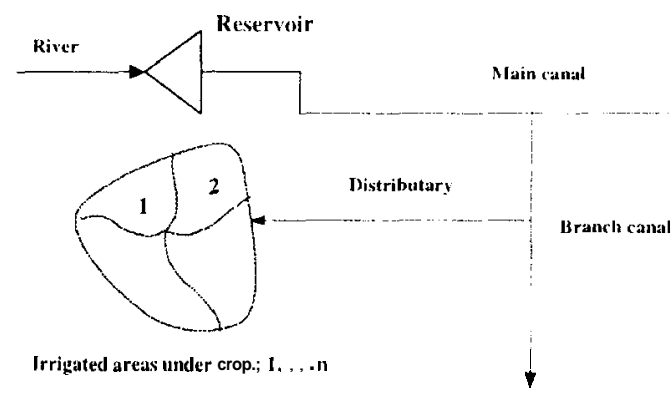

FIG. 1 ATYPICAL IRRIGATIONRESERVOIR SYSTEM

I. Department of Civil Engineering, Indian Institute of Science, Bangalorc

2. Regional Remote Sensing Service Center (RRSSC), Bangalore

Note : Written discussion of this paper will be open until 30th Junc 2004. 
Figure I shows a typical irrigation reservoir system in which water from the reservoin is conveyed through a system of main, branch and distributary canals and allocated to crops. The present study is concerned with only the command area under a distributary. and the problem addressed is that of optimal water allocation to crops under deficit supply to maximize crop yield. Most earlier studies dealing with irrigation water allocation in coininand areas (c.g.. Rao et al.. 1990, Rao et al.. 1992. Dariane and Hughes, 1991. Mujumdar and Ramesh. 1997) have dealt with fixed (planned or assumed) crop areas throughout the crop season. The actual crop areas adopted in a season may he much different from the planned areas, especially in India where agriculture is practiced by small farmers with many constraints 011 the choice of crops grown, decisions on irrigation allocations must he made hased on the actual crop areas during a scason. As the crop scason progresses, crop identification from satellite images becomes more and more reliable, and procedures to update the allocation decisions based o $\mathrm{n}$ crop areas estimated from satellite imageries will he useful. In this paper, the main issue addressed is updation of the crop water allocation decisions based on the crop areas as obtained froni processed satellite data as and when such data becomes available during a crop season. An optimization model is developed to provide real-time decisions on crop water allocations. The model operates as follows: For a given supply schedule at the distributary, initially the irrigation allocations are obtained based on the planned crop areas at the beginning of the season to optimize the crop yield at the end of the season. These allocations are followed in real time until updated information on crop areas becomes available from the processed satellite data. The model then updates the irrigation allocation decisions for the remaining periods in the season based on the corrected crop areas. Such updation of allocation decisions may he necessary typically once during a crop scason - when the crop spectral signatures arc expected to be more clearly detected by satellite imageries. The specific objective of this paper is to devclop an optimization model leading to a decision making mechanism for crop water allocation in a canal command area. using remotely sensed data.

The model developed prescribes water allocation policy starting with known values of canal discharge, rainfall in the command area, crop areas and crop soil moistures. A detailed soil moisture balance within the optimization model gives the crop response to water allocation. The objective function of the optimization model is the minimization of evapotranspiration deficits of the crops weighted with crop yield sensitivity factors, which is used as a measure for maximizing the crop yield in the canal command area. The model is applied to the case study of the coininand area of Distributary No. 36 in the Tunga Bhadra left hank command. Procedure of obtaining updated allocation decisions is demonstrated through one year of historical data for which processed satellite information on crop areas in the command area has been oblained from RRSSC. Bangalore (RRSSC. 1990). For a discussion on crop identificaltion with satcllitc imageries, readers are referred to standard texthooks on Remote Sensing applications (e.g., Lillesend and Kicfer, 2002).

The following sections discuss the details of the optimization model, and its use in real time water allocations in canal coininand areas.

\section{OPTIMIZATION MODEL}

At a given decision period (such as a Ien-day period) in a crop scason, the optimization model solves the problem of obtaining water allocations during cach of the remaining periods 
in the year (including the current period, for which the decision is sought) I'or known crop areas, rainfall in the command area, initial values of soil moistures of individual crops and canal discharges during all decision periods in a season. Tho model considers crop response to a delicit supply through yield sensitivity factors and minimizes weighted evapotranspiration deficit to ensure maximum crop production. The problem is formulated as linear programming problem

\section{Objective Function}

The motivation for the objective function is the crop yicld production function which relates the crop yield to evapotranspiration (ET)deficit over an entire growth stage. A simple approach of obtaining water allocation policy for irrigaling a single crop in the conmand area would be to solve an optimization problem with growth stages of the crop as decision periods and then operate the irrigation system during shorter intra-growth stage pcriods so iis to meet these allocation targets to the extent possible. However. since the growth slages of the crop are normally much larger than the intra growth stage intervals in which irrigations are applied it is necessary that the variations in canal discharge and soil moisture during these smaller intervals are all included in the model that detcrmines the allocation policy. Thercfore, the decision intervatin for which the optimization model provides releases must he the intervals at which the irrigation is actually applied on tlie ficld. Also. in the context of irrigation of multiple crops tlie growth stages of one crop are not equal in length to those of the other crops and therefore tlie optimization model must necessarily deal with much smaller intervals than the growth stages. The objective function should be appropriately constructed to take this into account. Keeping this in view, the following objective function is considered lor the allocation pi-ohlem:

$$
\begin{array}{r}
\operatorname{Min} \sum_{c=1}^{N} \sum_{t=t_{1}}^{T} \mathrm{Ky}_{c}^{\prime}\left(1-\frac{\mathrm{AET}_{c}^{\prime}}{\mathrm{PET}_{c}^{\prime}}\right) \\
\text { or } \operatorname{Max} \sum_{i=1}^{N} \sum_{t=t_{n}}^{T} \mathrm{Ky}_{c}^{t}\left(\frac{\mathrm{AET}_{c}^{!}}{\mathrm{PET}_{c}^{!}}\right)
\end{array}
$$

where. $K y^{\prime}$ is the crop yicld factor. $\Lambda E T$ ' is the actual evapotranspiration of crop c in period $t$ and PET' is the potential cvapotranspiration of crop $\mathrm{c}$ in period $t$. The model is solved from the current time period $t_{n}$ in real time until the last ume period $\mathrm{T}$ in the crop season. The summation term over time in the objective function reflects this.

The yield factors $\mathrm{Ky}$.' reflect the sensitivity of a crop $\mathrm{c}$ to water deficit in a period $\mathrm{t}$. The highes the value of Ky the higher will be the reduction in the crop yield for a given deficit. The yick factors are normally specilied only for a growth slage of a crop and not for individual periods within tlie growth stage. They are used in this study mainly as weighting factors for the crops and are assumed for each inti-a growth stage period to be the same as that for the entire growth staece (Raoet al. 1990). Vedula and Mujumdar. 1992). Thus in a period where a shortage of water exists a crop with a higher sensitivity should get more water than that with a lower sensitivity. other inlluencing factors (such as the PET and the crop area) being the same. 


\section{Constraints}

The constraints are formulated to represent soil moisture balance, relationship between evapotranspiration ratio and available soil moisture, and water availability constraints.

\section{Soil Moisture Balance}

When adecuate moisture is lreely available to completely meet the needs of the vegetation fully covering an area, the resulting cvapotranspiration is called potential evapotranspiration (PET).The evapotranspiration. occurring in a specific situation in the field, is called the actual evapotranspiration (AET). It varies with time periods ( $\mathrm{t}$ ) and crop type (c). The soil moisture at the hepinning of the current period $t_{p}$ is known for all crops. Starting with this known soil moisture, the soil moisture values at the beginning of all subsequent periods up to the end of the season are computed by the soil moisture continuity, given by:

$$
\theta_{c}^{t+1} D_{c}^{t+1}=\theta_{c}^{t} D_{c}^{t}+R A I N^{t}+\left(q_{c}^{t} / A_{c}\right)-A E T_{c}^{\prime}+\theta_{0}\left(D_{c}^{t+1}-D_{c}^{t}\right)-D P_{c}^{\prime}
$$

where $\theta_{c}^{t}$ is the soil moisture of crop $c$ at the beginning of the period $t, D_{c}^{\prime}$ is the root depth of crop $c$ in period $t$, RAIN' is the effective mainfall in the command area in period $t, q^{t}$, is the irrigation allocation to crop $c$ in period $t . A_{c}$ is the area of crop c. AET' is the actual evapotranspiration of crop $\mathrm{c}$ in period $t, \theta_{0}$ is the initial soil moisture in the soil zone into which the crop root extends at the beginning of period $t+1$, and $D P^{\prime}$, is the deep percolation (see. for details, Mujumdar and Vedula. 1992). The soil moisture values $\theta^{t}$ and $\theta_{0}$ arc in units of depth per unit root depth, allocations $\mathrm{g}_{\mathrm{c}}{ }^{1}$ in volume units, area $\mathrm{A}_{\mathrm{c}}$ is in area units and all other terms are in depth units.

\section{AET-PET Relationship}

The relationship between AET/PET ratio and the available soil moisture is approximated by a lincar relationship, with $\mathrm{AET}=0$, when the available soil moisture is zero (corresponding to the actual soil moisture at wilting point) and $A E T=P E T$ when the available soil moisture is cqual to the maximum available soil moisture (corresponding to the actual soil moisture at field capacity). $\mathbf{0}$, and $\theta_{w}$ are as soil moistures at field capacity and wilting point respectively, in depth per unit depth (of root zone) units. This condition is written as:

$$
A E T_{c}^{i} \leq \frac{\left(\theta_{c}^{\prime} D_{c}^{t}+R A I N^{\prime}+\left(q_{c}^{\prime} / A_{c}\right)\right)-\theta_{w} D_{c}^{\prime}}{\left(\theta_{t}-\theta_{u}\right) D_{c}^{\prime}} \times P E T_{r}^{\prime}
$$

$$
A E T^{\prime} \leq P E T^{\prime}
$$

Equation (5) is necessary along with equation (4) to restrict the maximum value of the actual cvapotranspiration to the potential evapotranspiration. 


\section{Water Availability Constraint}

The total water allocated among crops, $\Sigma \mathrm{q}_{\mathrm{c}}{ }^{\prime}$, in time period $\mathrm{c}$. must be less than or equal to the maximum available water (volume) through canal discharge in that time period $\left(Q_{\max }^{\prime}\right)$.

$$
\sum_{i=1}^{N} q_{i}^{\prime} \leq Q_{\max }^{\prime}
$$

where $\mathrm{N}$ is the number of crops present in period $\mathrm{t}$

The LP model is thus written as,

$$
\operatorname{Max} \sum_{i=1}^{N} \sum_{t=\mathrm{t}_{\mathrm{p}}}^{T} K y_{c}^{t}\left(\frac{A E T_{c}^{t}}{P E T_{c}^{t}}\right)
$$

subject to

$$
\begin{aligned}
& \theta_{r}^{\prime+1}=\theta_{c}^{t}+\left(q_{c}^{t} / A_{c}\right)+R A I N-A E T_{r}-D P_{c}^{\prime} \quad \forall c, t \\
& A E T_{c} \leq\left(\theta_{r}^{t}+\left(q_{c}^{\prime} / A_{c}\right)+R A I N_{r}-\theta_{u}\right) \times \frac{P E T_{r}}{\left(\theta_{r}-\theta_{w}\right)} \quad \forall c, t
\end{aligned}
$$

$$
A E T \text { I } P E T \quad \forall c, t
$$

$\theta^{\prime+1} \geq \theta_{1} \times \beta^{\prime} \quad \forall c, t$

$D P^{\prime} \leq M \times \beta_{t}^{t} \quad \forall c, t$

$\theta_{u} \leq \theta_{c}^{\prime+1} \leq \theta_{f} \quad \forall c, t$

$$
\sum_{,=1}^{N} q_{c}^{\prime} \leq Q_{\max }^{t} \quad \forall t
$$

and non-negativity of all variables

Note that the term $D^{1}$ (appearing in Eqs. 3 and 4), representing the root depth of crop $\mathrm{c}$ in period $\mathbf{I}$ is absent in the formulation, (7-14) cis the formulation is presented for a constant root depth, and in the application, a maximum root depth for each crop is used. The soil morsture values represented in this model all correspond to the maximum root depth, and therefore arc expressed in depth units rather than in depth per unit depth (of root zone) units. Constraints (11) and (12) arc introduced to ensure that the deep percolation occurs only when the soil moisture is at ficld capacity. The variable $\beta_{c}^{t}$ in these constraints is an integer, binary variable, and $M$ is a large number (of the order 20000). In addition to these constraints, a minimum 
allocation constraint of the form, $q_{c}^{t} \geq \alpha Q_{\text {max }}^{1}$ may be added in certain applications where a minimum amount of water is to be ensured for cach crop. The coefficient $\alpha$ may be chosen appropriately by the decision maker in such cases.

In the model, the irrigation allocation to a crop in a period is based on (a) its current moisture status. which is the net effect of water supplied to the crop (through irrigation allocations and precipitation) from the beginning of the season up to the beginning of that period. (b) available water for irrigation (through canal discharge in that period), and (c)coinpetition for water with other crops. The condition of competition with other crops is introduced through use of crop yield factors, Ky. in the objective funclion which indicate the sensitivity of a crop to a deficil supply, and which vary with the crop growth stages. The state variable for crop production indicates the production poteniial of a crop from the current period to the end of the crop season.

\section{REAL-TIME IRRIGATION ALLOCATIONS}

The model is applied in real -time as follows: Skirting with the first time period in the season. planned crop areas are used in the model along with soil moistures at field capacity (because of pre-irrigation. before the starl of the season) and known rainfall to ohtain water allocations to crops for known canal discharge schedules. The allocation policy is implemented in real time until updated processed information on crop areas becomes available from the satellites. In a period in which this information becomes available. the optimization model is re-solved starting from that period up to the end of the season. to obtain updated decisions on water allocations. In a crop season. typically, about two such updations may he desirable. one early in the season and the other sometime after the mid season. This procedure is shown in Fig. 2.

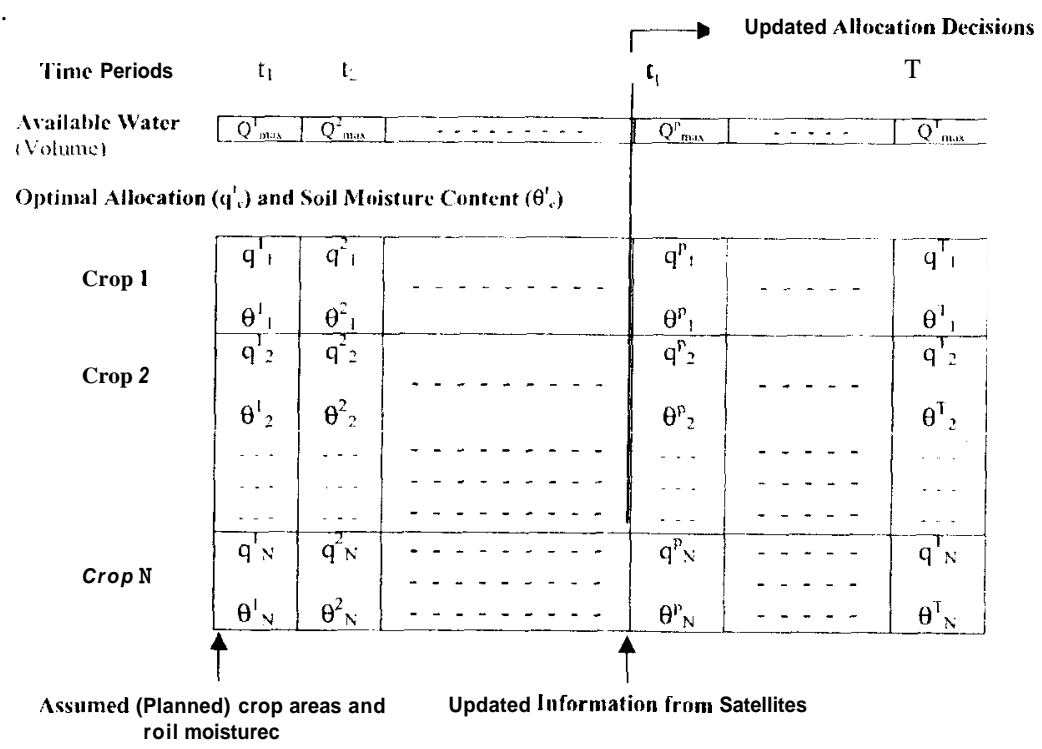

FIG. 2 REAL-TIME IRRIGATION SCHEDULING 


\section{CASE STUDY DISTRIBUTARY 36, TUNCABHADRA PROJECT}

Selection of the study area, through which the model application is demonstrated, was mainly governed by the availability of processed remotely scnscd data on crop areas in a canal command altea. Earlier studies carried out by the RRSSC (RRSSC, 1990. 1992) For crop arca identil'ication served as the main source of data. Based on the nature, extent and frequency of available processed data on crop areas in canal commands, the case study of irrigation command arca under the Distributary No. 36. of the Tunga Bhadra Left Bank Canal, Karnataka. India. was used for model application. Location of the study area is shown in Fig. 3. Main reasons for this choice of the study area are: (a) Already some studies arc carried out by the RRSSC, on crop identification in the particular command area and these studies are available in the form of published reports and papers, (h)Crucial data on cropped areas at two different dates in a year- (for demonstrating the model application), are available for the chosen command area. and (c) It was possible to obtain the corresponding canal discharge data for this particular distributary, from the Irrigation Department, Government of Karnataka.

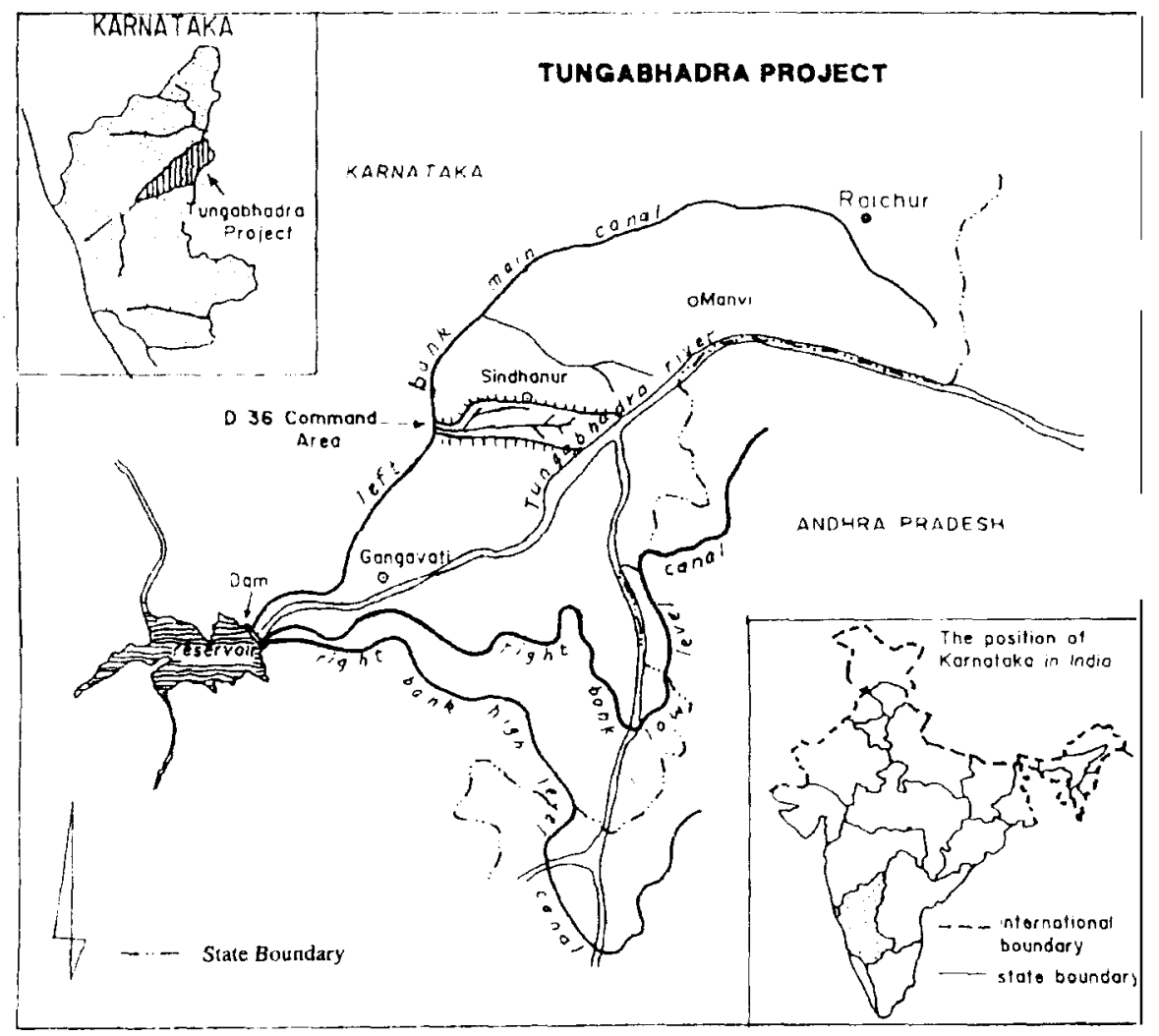

FIG. 3 LOCATION MAP OF THE DISTRIBUTARY NO. 36 OFTUNGA BHADRA LEFT BANK CANAL 
It is assumed that Kharif season spans from I" June to $30^{\text {in }}$ November; while Rabi season extends from I $^{\text {st }}$ Dec to $31^{\text {st }}$ May. Each of the scasons is divided into I8 number of 10-day periods. Processed Satellite data is obtained from RRSSC (Manavalan et al., 1995) which uses the IRS-LISS 2 (with a spatial resolution of $36.25 \mathrm{~m}$ ) satellite imageries.

Relevant information pertaining to the distributary 36 coininand area is given below:

Total Command Area: 18000 ha;

Soil Type: $\quad$ Raichur Clay;

Field Capacity: $\quad 33.2 \%$ :

Willing Point: $\quad 16.5 \%$;

Major Crops Grown:

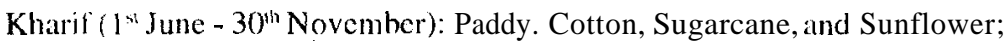

Rahi /Summer ( $1^{\text {st }}$ Dec - $31^{\text {st }}$ May): Paddy. Cotton, Sugarcane, Jowar, Groundnut (Cotton and Sugarcine are two seasonal crops, extending to both the seasons).

The daily discharges in the canal. daily rainfall data in the command area. crop coefficients, PET-values are collected from field measured data and available information in literature. Necessary processed data on cropped areas under the selected command has been collected from RRSSC, Bangalore. The data of the year 1989 and 1990, and the results of an earlier study hy the RRSSC (RRSSC, 1990) on these data are taken for the present study, as both remote sensing estimates and ground truth data of crop areas are available for these years. The multispectral classification technique, with supervisedclassification method, is used by RRSSC lor crop identification. Details of this procedure and discussion is available in Manavalan et al. (1995). Data on discharges in the distributary are obtained from Karnataka Irrigation Department. Details of rainfall (RAIN'), maximum arailable flow $\left(\mathrm{Q}^{\prime}\right.$, , area from fiefd inspection and satellite imagery, values of PET for different $\mathrm{c}$ and $\mathrm{t}$, yield sensitivity factor for different time periods $\left(\mathrm{Ky}^{1}\right)$ are tabulated in tabular form. Table I gives the crop areas and durations. The spectral I-csponses of crops from which the crop areas are estimated are given in Table 2. Tables 3 and 4 give other relevant data used in the model application. The rainfall values presented in Table 3 are tnken as effective rainfall contributing to the soil moisture.

\begin{tabular}{|c|c|c|c|}
\hline \multirow{2}{*}{ Crop } & \multicolumn{2}{|c|}{ Cropped Area (Hectares) } & $\begin{array}{c}\text { Duration(t) }^{\sharp} \\
\text { (10 day periods) }^{*}\end{array}$ \\
\cline { 2 - 3 } $\begin{array}{c}\text { Area from Field } \\
\text { Inspection }\end{array}$ & $\begin{array}{c}\text { Area estimated from } \\
\text { Satellite imageries }\end{array}$ & \\
\hline \multicolumn{3}{|l}{} \\
\hline Paddly & 5578.79 & 6437.30 & $7-15^{\bullet}$ \\
\hline Suntlower & 1532.99 & 1426.80 & $3-13$ \\
\hline
\end{tabular}




\begin{tabular}{|c|c|c|c|}
\hline \multirow{2}{*}{ Crop } & \multicolumn{2}{|c|}{ Cropped Area (Hectares) } & $\begin{array}{c}\text { Duration(t) } \\
(10 \text { day periods) }\end{array}$ \\
\cline { 2 - 3 } & $\begin{array}{c}\text { Area from Field } \\
\text { Inspection }\end{array}$ & $\begin{array}{c}\text { Area estimated from } \\
\text { Satellite imageries }\end{array}$ & \\
\hline \multicolumn{3}{|c|}{} \\
\hline Paddy & 4421.02 & 5515.00 & $3-15$ \\
\hline Jowar & 1977.43 & 206.20 & $4-15$ \\
\hline Groundnut & 33.10 & 33.10 & $3-14$ \\
\hline \multicolumn{5}{|c|}{} & $7-18(\mathrm{~K})$ and $1-6(\mathrm{R})$ \\
\hline Colton(K) & 3338.82 & 2843.90 & $16-18(\mathrm{~K})$ and $1-15(\mathrm{R})$ \\
\hline Cotton(R)* & 3902.50 & - & $1-18(\mathrm{~K})$ and $1-15(\mathrm{R})$ \\
\hline Sugarcane & 82.57 & 263.90 & \\
\hline
\end{tabular}

TABLE-2

SPECTRAL RESPONSES OF DIFFERENT CROPS RECORDED IN VISIBLE AND NEAR-INFRARED CHANNELS OF IRS-LISS 2 * (Manavalan et al., 1995)

\begin{tabular}{|c|c|c|c|c|c|}
\hline \multirow{2}{*}{ SI. No. } & \multirow{2}{*}{ Category } & Band 1 & Band 2 & Band 3 & Band 4 \\
\cline { 3 - 6 } & Paddy & 48.29 & 27.36 & 22.45 & 65.97 \\
\hline 2 & Cotton(K) & 49.83 & 29.40 & 26.15 & 55.60 \\
\hline 3 & Cotton(R) & 51.21 & 29.99 & 28.58 & 48.75 \\
\hline 4 & Sunflower & 52.54 & 33.00 & 29.85 & 52.77 \\
\hline 5 & Groundnut & 49.58 & 32.05 & 24.21 & 72.21 \\
\hline 6 & Jowar & 49.50 & 30.14 & 23.73 & 75.48 \\
\hline
\end{tabular}

"Spectral response for the Sugarcane is obtained from first lo ur bands of LANDSAT Themalic Mapper data; these are 66.83, 3I.32, 24.32 and 12I.5I. 
TABLE-3

RAINFALL AND AVAILABLE IRRIGATION WATER*

\begin{tabular}{|c|c|c|c|c|}
\hline \multirow[b]{2}{*}{$\begin{array}{c}\text { Time Period } \\
\text { ( I0 day) }\end{array}$} & \multicolumn{2}{|c|}{ Kharif Season } & \multicolumn{2}{|r|}{ Rabi Scason } \\
\hline & $\begin{array}{l}\text { Rainfal l } \\
\text { (mm) }\end{array}$ & $\begin{array}{c}\text { Volume of } \\
\text { Water } \\
\text { Available } \\
\text { through Canal } \\
\text { Discharge (Mcum) }\end{array}$ & $\begin{array}{c}\text { Rainfall } \\
\text { (mm) }\end{array}$ & $\begin{array}{c}\text { Volume of Water Available } \\
\text { through Canal Discharge } \\
\text { (Mcum) }\end{array}$ \\
\hline I & 2.3 & 0.000 & 0.0 & 3.715 \\
\hline 2 & 2.1 & 0.000 & 0.0 & 3.715 \\
\hline 3 & 11.4 & 0000 & 9.2 & 4.086 \\
\hline 4 & 20.6 & 0.000 & 0.0 & 5.881 \\
\hline 5 & 159.5 & 0000 & 0.0 & 5.881 \\
\hline 6 & 6.4 & 0.000 & 0.0 & 0.469 \\
\hline 7 & 27.8 & 4970 & 0.0 & $5.72 \mathrm{I}$ \\
\hline$x$ & 9.1 & 3.970 & 0.0 & $5.72 \mathrm{I}$ \\
\hline 9 & 4.9 & 5.468 & 0.0 & 4.576 \\
\hline 10 & 13.9 & 5.687 & 0.0 & 5.676 \\
\hline 11 & 71.8 & 5.687 & 0.0 & 5.676 \\
\hline I? & 161.7 & 5687 & 0.0 & 6.244 \\
\hline 13 & 35.6 & 5.574 & 0.0 & 5.011 \\
\hline 14 & 0.0 & 5.574 & 6.7 & $5.0 \mathrm{II}$ \\
\hline 15 & 0.0 & 6.131 & 0.0 & $5.01 \mathrm{I}$ \\
\hline 16 & 2.8 & 5.067 & 26.9 & 0.000 \\
\hline 17 & 2.5 & 5.667 & 67.3 & 0.000 \\
\hline 18 & 0.0 & 5.667 & 130.4 & 0.000 \\
\hline
\end{tabular}

*Rainfall based on daily values recorded in a gauge in the command area lor 1989-90: Volume of water computed based on monthly average discharges in the distributary for the year 1989 90 .

TABLE-4 PET\% VALUES (mm) FOR DIFFERENT CROPS AND TIME PERIODS

\begin{tabular}{|c|c|c|c|c|c|c|c|c|c|c|c|}
\hline \multirow[b]{2}{*}{$\begin{array}{l}\text { Perind } \\
\text { I0 daly }\end{array}$} & \multicolumn{5}{|c|}{ Khariles in } & \multicolumn{6}{|c|}{ Rabi crops } \\
\hline & Padd! & Cotton & $\begin{array}{l}\text { Cotloil } \\
(\mathrm{R})\end{array}$ & Sluviluani & Suntlower & Pildely & $\begin{array}{c}\text { Conlon } \\
(\mathrm{K})\end{array}$ & Cinton & Sugirciank & lowill & $\begin{array}{c}\text { Giround- } \\
\text { nut }\end{array}$ \\
\hline I & 0.00 & 0.00 & 0.00 & 33.89 & 0.00 & 0.00 & 21.78 & 19.06 & 24.51 & 0.00 & 0.00 \\
\hline 2 & 0.00 & 0.00 & 0.00 & 36.04 & 0.00 & 0.00 & 20.1 & 17.59 & 22.62 & 0.00 & 0.00 \\
\hline 3 & 53.30 & 0.00 & 0.00 & 31.96 & 15.98 & 37.00 & 26.94 & 35.35 & 30.30 & 0.00 & 13.47 \\
\hline 4 & 42.40 & 0.00 & 0.00 & 25.45 & 12.73 & 23.30 & 16.91 & 22.20 & 19.03 & 6.34 & 8.46 \\
\hline 5 & 0.00 & 0.00 & 0.00 & 30.45 & 50.75 & 32.10 & 18.97 & 30.65 & 26.27 & X.76 & 11.68 \\
\hline 6 & 0.00 & 0.00 & 0.00 & 25.91 & 43.19 & 40.00 & 23.60 & 38.22 & 32.76 & 25.48 & 2548 \\
\hline
\end{tabular}




\begin{tabular}{|c|c|c|c|c|c|c|c|c|c|c|c|}
\hline \multirow[b]{2}{*}{$\begin{array}{l}\text { Period } \\
10 \text { day) }\end{array}$} & \multicolumn{5}{|c|}{ Kharif crops } & \multicolumn{6}{|c|}{ Rabi crops } \\
\hline & Paddy & Cotton & $\begin{array}{c}\text { Cotton } \\
\text { (R) }\end{array}$ & Sugaranc & Sunllow & Paddy & $\begin{array}{l}\text { Cotton } \\
\text { (K) }\end{array}$ & Cotton & watedne & Jowar & $\begin{array}{c}\text { Ground. } \\
\text { nul }\end{array}$ \\
\hline 7 & & & & & & & & & 34.76 & 27.10 & 27.1 \\
\hline 8 & & & & & & & 00 & 4219 & & 28. & 28.13 \\
\hline 9 & 44.90 & 28.57 & 0 & 24.49 & 28. & 36.7 & 0.00 & 3506 & 30.05 & 33. & 30.05 \\
\hline 10 & 44.70 & 28.47 & 0. & .4 & 28. & 4950 & 0.00 & 3601 & 40.50 & 45.01 & 40.5 \\
\hline 11 & 26.30 & 16.76 & 0 & .36 & 16.76 & 52.80 & .00 & 3842 & 43.20 & 38.42 & 43.22 \\
\hline 12 & 51.70 & 49.39 & 0.00 & 28.22 & 18. & 7310 & 0.00 & 4872 & 36.54 & 48.72 & 42.63 \\
\hline 13 & 35.90 & 34.25 & 0.0 & & 13. & 68.40 & 0.00 & 4558 & 34.19 & 45.58 & 39.8 \\
\hline 14 & 36.90 & 32.27 & 0.00 & 18.44 & 0.00 & 74.60 & 0.00 & 4040 & 37.30 & 49.73 & 31.08 \\
\hline 15 & 33.50 & 37.04 & 0.00 & 21.17 & 0.00 & 64.40 & 0.00 & 4404 & 40.66 & 33.88 & 000 \\
\hline I6 & 0.00 & 32.34 & 12.32 & 18.48 & & 0.00 & 0.00 & 000 & 0.00 & 0.00 & 0.00 \\
\hline 17 & 0.00 & 24.92 & & 14.24 & 0.00 & 0.00 & 0.00 & 000 & 0.00 & 0.00 & 0.00 \\
\hline 18 & 0.00 & 30.65 & 11.68 & 17.51 & 0.00 & 0.00 & 0.00 & 000 & 0.00 & 0.00 & 0.00 \\
\hline
\end{tabular}

PET value of 0.0 for a crop in a period indicates that the crop is not present in that period.

* Compulcd from observed daily Pan Evaporation data for 1989-90, using crop coefficients.

\section{RESULTS AND DISCUSSION}

The processed satellite data for area are used to obtain optimal water allocations tor the crops. Plamed allocations are oblained for demonstation of the methodology, using the field inspected data. and the updated allocutions are obtained hy using the satcllite imagery data. Allocitions to paddy were artificially controlled in the model to accum lor about $6 \mathrm{~cm}$ of standing water throughout the growing season. The resulting LP model was solved using the LINGO (LINear and General Optinization) package. The maximum size of the LP model for the kharil season was 450 variables with 558 constraints and for the Rahi season it was 540 variables with 666 constraints. Note that when the model is solved the second time in a season with updated crop areas available mid-season, the six of the LP problem is smaller as the number of periods included in the optimization is smaller.

To cxamine the performance of this irrigation water allocation model in terms of the crop response to various levels of available water. the AET values are obtained for different values of available canal discharge, with respect to optimal allocations resulting from the model for the planned areas of crops. Fig. 4 shows tlic pattern of variation ol AET values for rabi cotton with available canal discharge. The AET is a measure of crop response to available soil moisture which depends on the irrigation allocation, apart from the rainfall and initial soil mossture. When the moisture is adequate to meet the evapotranspiration demands of the crop, AET will be cqual to PET. In extreme deficit situations AET will be much lower than the PET, as may be seen from Fig. 4. The variation of AET shown in tlic figure for cotton results from the optimal allocations to that crop lor different levels of water availability. The crop yicld is optimum when the actual evapotranspiration is equal to the potential evapotranspiration during all periods in the season. Analyses of model results toi- various levels of water availability will be usclul in designing the canal discharge policies in the case of deficit supplies. 


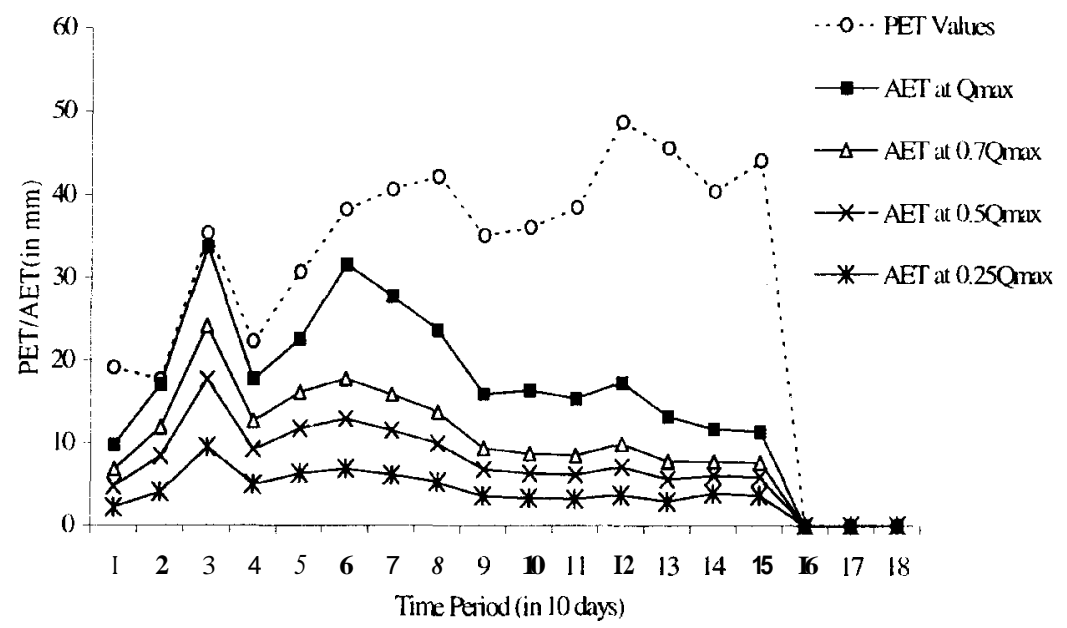

FIG. 4 VARIATION OF AET WITH $Q_{\text {max }^{\prime}}$ FOR RABI COTTON

From the optimization model (Eq. 7 to 14), it can be observed that, the change in area of one crop can cause a significant change in water allocation for other crops. In this model, due to unavailability of area data for Cotton, the field inspected and satellite area data are assumed the same. However, as shown in Fig. 5, the water allocations to the cron may be significantly different in some periods after updation of the policy, because of change in irrigated areas of other crops, affecting competition among crops for available of water. As seen from Table I. a significant error exists in estimation of the crop area for Rabi Jowar. The planned and updated allocations for this crop are shown in Fig. 6. If improved crop area estimates obtained from processed data of satellite imageries may be obtained, the water allocation decisions obtaincd from the model will be more useful in field implementation.

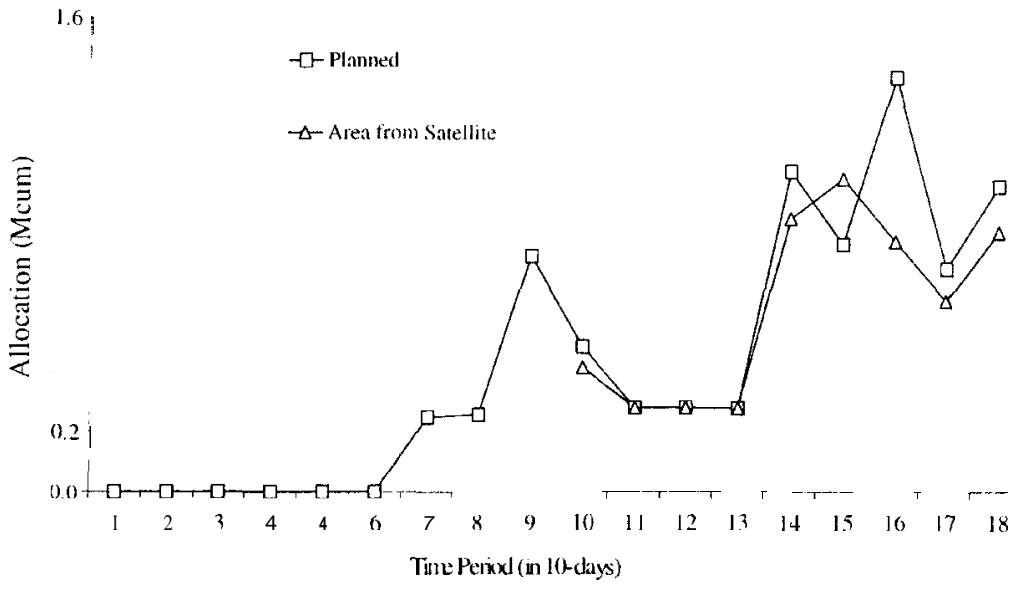

FIG. 5 PLANNED AND UPDATED ALLOCATION FOR KHARIF COTTON 


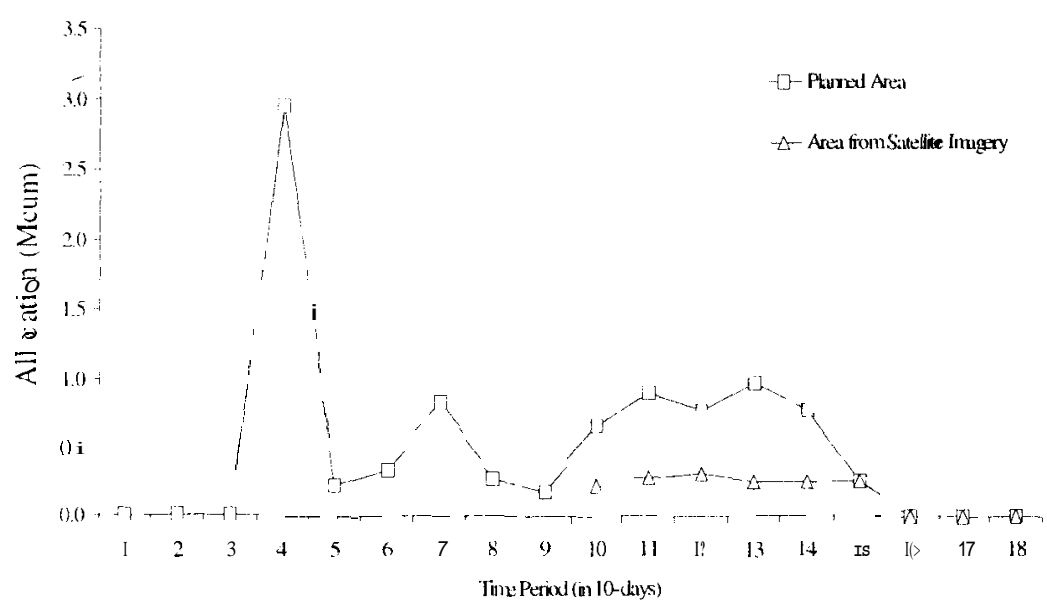

FIG. 6 PLANNED AND UPDATED ALLOCATION FOR RABI JOWAR

Results given in Figs 5 and 6 are understood as follows: In both the Kharif and the Kabi seasons, the processed satellite data on crop areas is available at the beginning of the $10^{\text {th }}$ decision interval. Starting with the planned crop areas, the irrigation allocations are obtained from the model solution for each season. These are shown by the allocations for planned areas in the two figures. At the decision interval 10 in both the Kharif and Rabi season, information on actual crop areas becomes available from the satellite imageries. The model is rerun, with these areas. from period 10 to the last period in the season, and the updated allocations are obtained. In real-time. these updated allocations arc meant to be followed from period 10 onwards. The updated allocations arc shown in the two figures (Fig.5 and Fig. 6) as allocations lor crop areas from satellite data. Note that in the absence of updation of the allocations, the allocations hased on planned areas would be followed which are much higher. in this case. for the two crops. The updated allocations also depend, apart from the crop arcas, on a number of other factors such as the crop sensitivity and the extent of competition with other crops reflected by the amount of water deficit.

For the case study used for model demonstration, the satellite data as well as field investigation (ground truth) data were available. The ground truth data is used only for validating the satcllite imagery data. Once the crop identitication is validated to be reasonably accurate for a command area, the processed data from satellite imageries may be used directly for optimal crop water allocations, thus avoiding the field surveys to obtain the actual crop areas. For the case study, a particular year (1989-90) has been used for demonsti-ation, and therefore the allocations shown in the figures are all only for that particular year. The main aim of this study has been to integrate the remotely sensed data on crop areas into an optimization model for obtaining crop water allocations.

\section{LIMITATIONS OF THE STUDY}

I. The crop area estimation from satellite imageries is not very accurate as seen from the ground truth data (Table 1). This introduces appreciable crrors in the water allocation 
policies. The model results will work better with hetter estimates of crop areas Ironi satellte imageries. The pattern recognit ion techniqtics used for crop identificalion can tic improved to a large extent by setting suitable values of classification accuracy and thishold set. The applied methodology for crop identification is also very much dependent on the selection of the date of collection of spectral response data for training areas. By choosing appropriate dates of satellite data based on crop calendar and further correctung them for change in atmospheric conditions. a better accuracy could be achieved.

2. The soil moisture values used in the model are simulated with a soil moisture balance equation. Ideally. sensor measured data - even with averaging over a large area - should he integrated into the real-time water allocation modcl.

3. Rainfall is considered ats a deterministic known value in the model. A real-time rainfall forecasting model, that uses the latest rainfall information, should be used to obtain rain fall forccasts. This is likely to yield better results, especially in the kharif scason.

\section{CONCLUSION}

A specilic objective of work presented in this paper is to develop a mathematical model leading to a decision making mechanism for crop water allocation in a canal corninand area. using remotely sensed data. For a known discharge in the canal, the model specifics the water allocations todifferent crops in ten-day time intervals. The model. when applied in real-time. provides guidelines to update the crop water allocntion decisions, from time to time. as and when fresh data on crop areas hecomes available. from remote sensing. Estimates ot input variables such as crop areas from remote sensing would improve irrigation water management in canal command areas. The future studies must focus on addressing uncertainty in the hydrologic variables to provide real-time irrigation water allocations in canal command areas.

\section{ACKNOWLEDGEMENT}

The authors thank the anonymous reviewers for providing very uselul suggestums and critical comments which improved the quality of presentation in the paper. The work presented in the paper was carried out in the project ISTC/MCV/PPM/123 sponsored by the ISRO-IISC space technology cell.

\section{REFERENCES}

Dariane, A. B. and Hughes. T. C. (1991). Application of Ci-op Yicld Functions in Reservoir Operation. Water Resources Bulletin. Vol. 27, No. 4. pp. 649-6.56.

Lillesand. T. M. and Kiefer. R. W. (7002). Remote Sensing and Image Intel-pi-etalion". Fourth Edition. John Wiley \& Sons, Inc.

Manavalan. P., Kesavasamy, K. and Adiga, S. (1995), Irrigated Crops Monitoring through Seasons using Digital Change Detection Analysis of IRS-LISS 2 Data. International Jl. of Remote Sensing, 16(4), 633-640.

Mujumdar. P. P. and Vedula. S. (1992). Performance Evaluation of an Irrigation System under Some Optimal Operating Policies. Hydrological Sciences JI., 37( I), 13-26. 
Mujumdar, P. P. and Ramesh, T. S. V. (1997). Real-time Reservoir Operation for Irrigation. Water Resources Research, Vol. 33, No. 5, pp. 1157-1164.

Rao, N. H.. Sarma, P. B. S. and Subhash Chander (1990). Optimal Multicrop Allocation of Seasonal and Intraseasonal Irrigation Water. Water Resources Research, Vol. 26, No. 4, pp. $551-559$.

Rao, N. H., Sarma, P. B. S. and Subhash Chander (1992). Real-rime Adaptive Irrigation Scheduling under a Limited Water-Supply. Agricultural Water Management, Vol. 20, pp. 267-279.

RRSSC (1992). Cropping Pattern Analysis in 36, Distributary Command of Tungabhadra Lclt Bank Canal using IRS LISS-2 Data. Repon - B/(003/92, Bangalore.

RRSSC (1990).Irrigated Landuse Study. RC:BG:WR:002:90, Bangalore.

Sarma, P. B. S. (2002). Water Resources and their Management lor Sustainable Agricultural Production in India. In :Rescarch Perspectives in Hydraulics and Water Resources. Rama Prasad and S. Vedula (Eds.), World Scientific, Singapore, pp.193-285.

Vedula, S. and Mujumdar, P. P. (1992). Optimal Reservoir Operation for Irrigation. Wat. Resour. Res. $28(1), 1-9$.

\section{NOTATIONS}

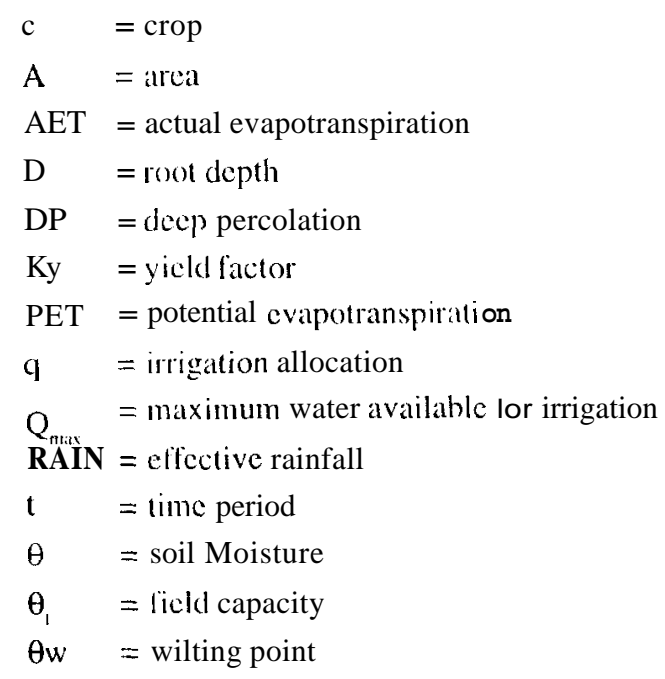

